\title{
Szívinfarktust túlélt betegek terápiahüsége a másodlagos megelőzés szempontjából fontos gyógyszeres kezelésekhez
}

\author{
Jánosi András dr. ${ }^{1}$ - Ofner Péter dr. ${ }^{1}$ - Kiss Zoltán dr. ${ }^{2}$ \\ Kiss Levente $\mathrm{dr}^{3}{ }^{3}$ - Kiss Róbert Gábor $\mathrm{dr}^{4}{ }^{4}$. Dinnyés József $\mathrm{dr} .^{5}$ \\ Járai Zoltán dr. ${ }^{6}$ - Nagy Gergely dr. ${ }^{7}$ \\ Veress Gábor $\mathrm{dr}^{8}{ }^{8}$ - Ferenci Tamás dr. ${ }^{9}$ \\ ${ }^{1}$ Gottsegen György Országos Kardiológiai Intézet, Budapest \\ ${ }^{2}$ Pécsi Tudományegyetem, Általános Orvostudományi Kar, \\ II. Belgyógyászati Klinika és Nefrológiai Központ, Pécs \\ ${ }^{3}$ Kazincbarcikai Kórház Nonprofit Kft., Kazincbarcika \\ ${ }^{4}$ Magyar Honvédség Egészségügyi Központ, Honvédkórház, Budapest \\ ${ }^{5}$ Vaszary Kolos Kórház, Esztergom \\ ${ }^{6}$ Szent Imre Egyetemi Oktatókórház, Budapest \\ ${ }^{7}$ Borsod-Abaúj-Zemplén Megyei Kórház, Egyetemi Oktatókórház, Miskolc \\ ${ }^{8}$ Állami Szívkórház, Balatonfüred \\ ${ }^{9}$ Óbudai Egyetem, Neumann János Informatikai Tanszék, \\ Élettani Szabályozások Csoport, Budapest
}

\begin{abstract}
Bevezetés és célkitüzés: A szerzők szívinfarktust túlélt betegek terápiahüségét (adherencia) vizsgálták a másodlagos prevenció szempontjából szóba jövő gyógyszerek esetén.

Módszer: A Nemzeti Szívinfarktus Regiszterben 2013. január 1. és 2014. december 31. között regisztrált szívinfarktusos betegek közül azok kerültek a vizsgált betegcsoportba, akik a heveny myocardialis infarctust túlélték és a kórházi kezelést követően 180 napig nem volt újabb eseményük. Ezen kritériumoknak 14843 beteg felelt meg, akiket egy évig követtek. Vizsgálták a sztatin, a béta-blokkoló, a thrombocytaaggregáció-gátló, valamint az angiotenzinkonvertáló enzim/angiotenzinreceptor-blokkoló kezeléshez való adherenciát. A „gyógyszerszedést” az Egészségbiztosító Pénztár gyógyszer-finanszírozási adatbázisa alapján követték. Az adherenciát az indexeseménytől a végpontig (vagy a cenzorálásig) eltelt idő és a kiváltott készítményekkel való ellátottsági idő hányadosaként határozták meg. Végpontnak a halált vagy az újabb infarktus előfordulását tekintették. Többváltozós modellel elemezték az adherenciát és a túlélést.

Eredmények: Jó adherenciát (>80\%) találtak a klopidogrel, sztatin, béta-blokkoló, aszpirin és ACEI/ARB esetén a betegek $64,9 \%, 54,4 \%, 36,5 \%, 31,7 \%$ és 64,0\%-ánál. Azoknál a betegeknél, akiknél az infarktus kezelésekor percutan intervenció történt, magasabb terápiahűséget találtak $(\mathrm{p}<0,01)$ minden gyógyszer esetén, kivéve a béta-blokkolókat $(\mathrm{p}=0,484)$. A többváltozós elemzés során igazolták, hogy a sztatin, klopidogrel, ACEI/ARB adherencia 25 százalékpontos növekedése a végpontok bekövetkezésének 10,1\%-kal $(\mathrm{p}<0,0001), 10,4 \%$-kal $(\mathrm{p}=0,0002), 15,8 \%$-kal $(\mathrm{p}<0,0001)$ kisebb kockázatával járt együtt. Az aszpirin- és a béta-blokkoló kezelés esetén az adherencia nem függött össze a végpontok bekövetkezésének kockázatával.
\end{abstract}

Következtetés: A sztatin, klopidogrel, ACEI/ARB kezelés esetén a magasabb adherencia jobb hosszú távú prognózissal járt együtt.

Orv Hetil. 2017; 158(27): 1051-1057.

Kulcsszavak: gyógyszer-adherencia, szívinfarktus, másodlagos megelőzés, infarktusregiszter 


\title{
Adherence to medication after myocardial infarction and its impact on outcome: a registry-based analysis from the Hungarian Myocardial Infarction Registry
}

\begin{abstract}
Introduction and aim: The aim was to study the patients' adherence to some evidence-based medication (statins, beta blockers, platelet and RAS inhibitors) after suffering a myocardial infarction, and its impact on the outcome. Method: Retrospective observational cohort study was carried out from the data of the Hungarian Myocardial Infarction Registry between January 1, 2013, and December 31, 2014. 14,843 patients were alive at the end of hospital treatment, from them, those who had no myocardial infarction or death until 180 days were followed for one year. The adherence was defined as the proportion of time from the index event to the endpoint (or censoring) covered with prescription fillings. The endpoint was defined as death or reinfarction. Information on filling prescriptions for statins, platelet aggregation inhibitors, beta blockers and ARB/ACEI-inhibitors were obtained. Multivariate regression was used to model adherence and survival time.

Results: Good adherence (>80\%) to clopidogrel, statins, beta blockers, aspirin and ARB/ACEI was found in $64.9 \%$, $54.4 \%, 36.5 \%, 31.7 \%$ and $64.0 \%$, respectively. Patients treated with PCI during the index hospitalization had higher adherence to all medication (all $\mathrm{p}<0.01)$, except for beta-blocker $(\mathrm{p}=0.484)$. Multivariate analysis confirmed that adherence to statins, to clopidogrel and ARB/ACEI-inhibitors was associated with $10.1 \%(\mathrm{p}<0.0001), 10.4 \%$ $(\mathrm{p}=0.0002)$ and $15.8 \%(\mathrm{p}<0.0001)$ lower hazard of endpoint respectively for $25 \%$ points increase in adherence, controlling for age, sex, performing of PCI, 5 anamnestic data and date of index event. Adherence to aspirin and beta blockers was not significantly associated with the hazard.

Conclusion: Higher adherence to some evidence-based medications was found to be associated with improved long term prognosis of the patients.
\end{abstract}

Keywords: adherence to medication, myocardial infarction, secondary prevention, myocardial infarction registry

Jánosi A, Ofner P, Kiss Z, Kiss L, Kiss RG, Dinnyés J, Járai Z, Nagy G, Veress G, Ferenci T. [Adherence to medication after myocardial infarction and its impact on outcome: a registry-based analysis from the Hungarian Myocardial Infarction Registry]. Orv Hetil. 2017; 158(27): 1051-1057.

(Beérkezett: 2017. április 24.; elfogadva: 2017. május 17.)

\section{Rövidítések}

$\mathrm{AMI}=$ akut myocardialis infarctus; AUC = area under curve HR = hazárdhányados; NSTEMI = ST-elevációval nem járó akut myocardialis infarctus; NSZR = Nemzeti Szívinfarktus Regiszter; OEP = Országos Egészségbiztosítási Pénztár; PCI = percutan coronaria-angioplastica; STEMI = ST-elevációval járó akut myocardialis infarctus; SWEDEHEART = Heart disease Evaluated According to Recommended Therapies

A gyógyszer-adherencia kérdése mindennapos probléma, mivel számos betegség esetén igazolták, hogy a kezeléshez való húség javítja a betegek prognózisát. A kérdés fontosságát igazolja az Egészségügyi Világszervezet e témában publikált összeállítása is [1]. Az Európai Kardiológus Társaság legutóbbi útmutatója [2] megállapítja, hogy a cardiovascularis halálozás elmúlt években megfigyelt csökkenésének mintegy $25 \%$-a az evidenciákkal alátámasztott gyógyszeres kezelés eredménye. Irodalmi adatok és a klinikai tapasztalat igazolja, hogy a szükséges gyógyszeres kezelés elhagyását számtalan tényezó befolyásolja: Nielsen [3] nagy esetszámú tanulmányában igazolta, hogy a napisajtóban közölt negatív hír a sztatinokkal kapcsolatban növelte a nonadherensek arányát, míg a pozitív tudósítás az adherensek arányát javította. A szívinfarktust túlélt betegek adherenciájával kapcsolatban több obszervációs vizsgálatot közöltek [4-6], de nagy populációt vizsgáló, klinikai adatokat is tartalmazó regiszteradatok ritkábban kerültek közlésre $[7,8]$. Vizsgálatunk célja, hogy a Nemzeti Szívinfarktus Regiszter adatbázisából kiindulva a gyógyszerár-támogatási adatbázist felhasználva vizsgáljuk a szívinfarktust túlélt betegek adherenciáját azon gyógyszerek esetén, amelyek tartós szedését a másodlagos prevenció szempontjából fontosnak tartjuk. Tanulmányunkban elemeztük az adherencia jelentőségét az újabb szívinfarktus és a túlélés szempontjából is.

\section{Betegek és módszer}

A Nemzeti Szívinfarktus Regiszter (NSZR) múködésével kapcsolatos módszertani kérdéseket korábbi közleményünkben részletesen bemutattuk [9]. Jelen tanulmányunkban az NSZR-ben 2013. január 1. és 2014. december 31. között regisztrált, szívinfarktus miatt kezelt betegek közül azok képezték vizsgálati csoportunkat, akik a kórházi kezelést túlélték. Ezen feltételnek 15585 beteg felelt meg, akik közül 9644 betegnél ST-elevációval járó myocardialis infarctus képezte a kezelés indokát. Az Országos Egészségbiztosítási Pénztár (OEP) gyógyszer-finanszírozási adatait felhasználva vizsgáltuk a másodlagos prevenció szempontjából legfontosabb négy ATC-kódba tartozó gyógyszerek vénykiváltási gyakorisá- 
gát (ATC-kód: C07, C09, Cl0, B01). Ennek segítségével a sztatin, a béta-blokkoló, a thrombocytaaggregációgátló, illetve RAS-gátló (ACEI/ARB) gyógyszerekkel kapcsolatosan végeztünk adherenciavizsgálatot. A betegeket egy évig követtük és vizsgáltuk az újabb myocardialis infarctus és a halál előfordulását, amelyeket végpontoknak tekintettünk. Az adherencia vizsgálatának szempontjából azon betegeket vettük figyelembe, akiknél az indexeseményt követő 180 napon belül új esemény (myocardialis infarctus, illetve halál) nem fordult elö. Ezen feltétel figyelembevételével az adherenciaadatok 14843 betegre vonatkoznak.

\section{Statisztikai elemzés}

A kategoriális adatokat gyakoriság (arány), a folytonos adatokat átlag (medián) $\pm \mathrm{SD}(\mathrm{IQR})$ (minimum-maximum) formában adjuk meg. A nem hiányzó értékek számát mindenhol közöljük.

$\mathrm{Az}$ egyváltozós túlélési görbéket nemparaméteres Kaplan-Meyer-eljárással határoztuk meg, a végpontig eltelő idő többváltozós modellezése Cox-regresszióval történt. A többváltozós modellhez a vizsgált adherencián túl magyarázó változóként hozzáadtuk az alany nemét, életkorát, a PCI megtörténtének tényét, az indexesemény idôpontját (hónapként) és öt anamnesztikus

1. táblázat | A 2013. január 1. és 2014. december 31. között regisztrált betegek demográfiai adatai

\begin{tabular}{lll}
\hline & STEMI $(\mathrm{n}=8940)$ & NSTEMI $(\mathrm{n}=9644)$ \\
\hline Férfi & $\mathrm{n}=8940$, & $\mathrm{n}=9645$, \\
& $5393(60,3 \%)$ & $5526(57,3 \%)$ \\
\hline $\begin{array}{l}\text { A férfiak életkora } \\
\text { (év) }\end{array}$ & $\mathrm{n}=5393$, & $\mathrm{n}=5526$, \\
& $(16,5)(17-101,3)$ & $(16,8)(22,9-99,5)$ \\
\hline A nók életkora & $\mathrm{n}=3547$, & $\mathrm{n}=4119$, \\
(év) & $69,3(70,2) \pm 12,9$ & $72,1(73,8) \pm 12$ \\
& $(19,8)(25,3-102,1)$ & $(17,6)(28,4-100,9)$ \\
\hline Utánkövetési idó & $\mathrm{n}=8940,303,2$ & $\mathrm{n}=9645,290,6$ \\
(nap) & $(365) \pm 126,2(0)$ & $(365) \pm 130,8(102)$ \\
& $(0-365)$ & $(0-365)$ \\
\hline Kórelőzményben & $\mathrm{n}=8175$, & $\mathrm{n}=8876$, \\
MI & $1528(18,7 \%)$ & $2825(31,8 \%)$ \\
\hline Kórelőzményben & $\mathrm{n}=8049$, & $\mathrm{n}=8725$, \\
stroke & $778(9,7 \%)$ & $1215(13,9 \%)$ \\
\hline Hypertonia & $\mathrm{n}=8493$, & $\mathrm{n}=9312$, \\
& $6359(74,9 \%)$ & $8011(86 \%)$ \\
\hline Diabetes mellitus & $\mathrm{n}=8139$, & $\mathrm{n}=8930$, \\
& $2341(28,8 \%)$ & $3448(38,6 \%)$ \\
\hline Perifériás & $\mathrm{n}=7520$, & $\mathrm{n}=8224$, \\
érbetegség & $932(12,4 \%)$ & $1695(20,6 \%)$ \\
\hline
\end{tabular}

$\mathrm{MI}=$ myocardialis infarctus, NSTEMI = ST-elevációval nem járó myocardialis infarctus; STEMI = ST-elevációval járó szívinfarktus. A diszkrét változók esetén az abszolút számot és a százalékot tüntettük fel. A folyamatos változók esetén a középérték került feltüntetésre. adatot (korábbi infarktus, korábbi stroke, hypertonia fennállása, diabetes fennállása, perifériás érbetegség fennállása), hogy kiszúrjük őket, mint potenciális confoundereket (zavaró változó, azaz olyan tényezô, ami egyszerre befolyásolja a végpont előfordulását, és függ össze a vizsgált változóval, a gyógyszer-adherenciával). A folytonos változókat (életkor, adherencia, dátum) korlátozott köbös spline-nal kibontva raktuk bele a modellbe, hogy megengedjük a potenciálisan nemlineáris hatásukat, de ha az eltérés a normalitástól nem volt szignifikáns, akkor a normális modellt használtuk (prespecifikált teszt). A limitet itt $\mathrm{p}=0,001$-re állítottuk (hogy inkább engedjük a jobban interpretálható lineáris modellek használatát a rendkívül nagy mintanagyság mellett is). A hazárd proporcionalitását Grambsch és Therneau [10] szokásos tesztjével ellenőriztük (itt $\mathrm{p}=0,05$-os limit mellett). A modelleket "area under the curve"-vel (AUC) jellemeztük (ROC-görbe alatti terület), amelyet bootstrappel korrigáltunk a túlilleszkedés okozta optimizmus elkerülésére (belső validáció). Az eredményeket hazárdhányados (HR) formában adjuk meg, 95\%-os konfidenciaintervallummal.

$\mathrm{Az}$ adherenciát logisztikus regresszióval modelleztük (a fentihez hasonló keretben), eredményváltozónak a $80 \%$ feletti értéket véve.

\section{Eredmények}

\section{Demográfia, társbetegségek}

A betegek demográfiai adatait és társbetegségeit az 1. táblázatban tüntettük fel az infarktus típusa szerint. A férfiak aránya mind az ST-elevációval járó (STEMI), mind az ST-elevációval nem járó (NSTEMI) infarktus esetén gyakoribb volt, míg a társbetegségek előfordulása az NSTEMI-csoportban volt gyakoribb, és az ebbe a csoportba tartozó betegek idősebbek is voltak.

\section{Kórházi kezelés}

Az akut myocardialis infarctus (AMI) miatt kezelt betegek 65,6\%-ánál történt percutan coronariaintervenció (PCI). Az invazív kezelésre a STEMI-csoport betegeinek 78,7\%-ában került sor, míg az NSTEMI-betegcsoportban ez az arány $52,5 \%$.

\section{Eseménytelen túlélés és a primer végpontok elófordulása}

Az utánkövetési idő alatt a betegek 40,4\%-ában következett be primer végpontnak tekintett esemény (újabb myocardialis infarctus, illetve halál). A betegcsoportok eseménymentes túlélési görbéjét az 1 . ábra mutatja. Többváltozós elemzés során (a gyógyszer-adherenciát figyelmen kívül hagyva) minden társbetegség (a hypertonia kivételével) a prognózis szempontjából jelentősnek bizonyult. A részletes adatokat a 2. táblázatban tüntettük fel. 


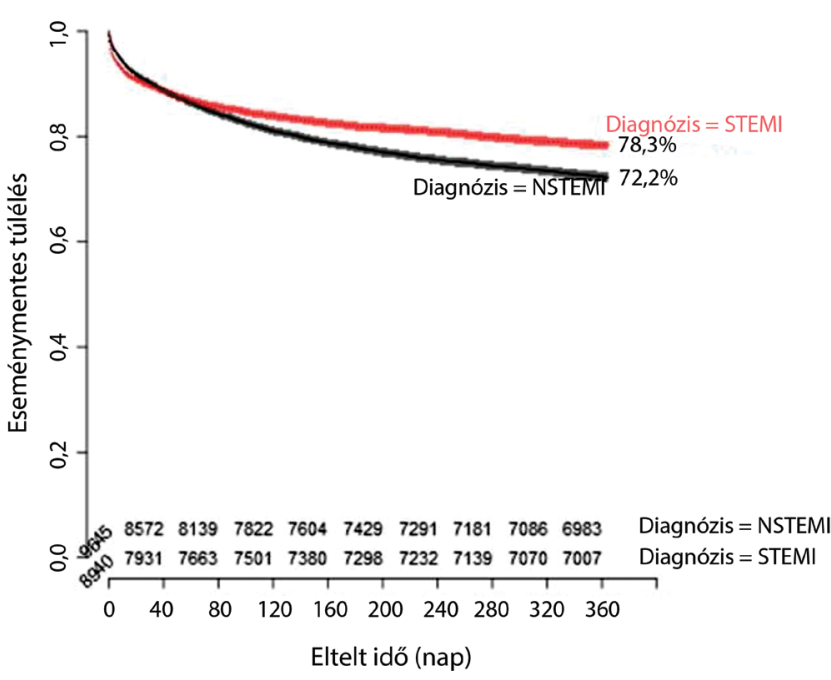

1. ábra A betegcsoportok eseménymentes túlélési görbéje

\section{A kórházi elbocsátáskor alkalmazott gyógyszeres kezelés és a terápiabüség}

A kórházi elbocsátáskor alkalmazott és a továbbiakban javasolt gyógyszeres kezelést a 3. táblázatban tüntettük fel. A betegek igen nagy százaléka (80-90\%) részesült az evidenciákkal alátámasztott gyógyszeres kezelésben a kórházi távozáskor. Az egyéves utánkövetés idején jó adherenciát (>80\%) a klopidogrel, ACEI/ARB, sztatin, béta-blokkoló, aszpirin esetén a betegek $64,9 \%, 64 \%, 54,4 \%$ 36,5\%,31,7\%-ánál találtunk.

\section{Az adherenciát befolyásoló tényezốk}

A PCI-kezelésben részesülő betegek adherenciáját - a béta-blokkolók kivételével - magasabbnak találtuk: a klopidogrel OR = 2,05 (95\%-os CI 1,87-2,25; p<0,0001), az ACEI-inhibitor/ARB OR = 1,25 (95\%-os CI 1,15-1,37; $\mathrm{p}<0,0001)$, a sztatin: $\mathrm{OR}=1,25$ (95\% CI-os 1,15-1,37; $\mathrm{p}<0,0001)$ és az aszpirin OR = 1,36 (95\% CI-os 1,25$1,50 ; \mathrm{p}<0,0001)$. A béta-blokkoló esetén ez az összefüggés nem igazolódott: OR = 1,03 (95\% CI-os 0,94-1,18; $\mathrm{p}=0,484)$. Az életkor szerepét vizsgálva azt találtuk, hogy a 60-70 év közötti betegeknél volt a legmagasabb $a z$ adherencia, az ennél fiatalabb, illetve az ennél idősebb betegcsoportokban az adherencia csökkent. Azon betegcsoportban, akiknél a kórelőzményben myocardialis infarctus szerepelt, az adherencia alacsonyabb volt: a sztatin $\mathrm{OR}=0,7$ (95\%-os CI: 0,64-0,77; p<0,001), a klopidogrel OR $=0,83(95 \%-$ os CI: $0,75-0,91 ; p=0,001), a z$ ACEI/ARB kezelés OR = 0,74 (95\%-os CI: 0,67-0,81; $\mathrm{p}<0,001)$, valamint az aszpirinkezelés $\mathrm{OR}=0,82(95 \%$-os CI: $0,74-0,91 ; p=0,001)$. A béta-blokkolónál ez az összefüggés nem igazolódott: $\mathrm{OR}=0,93$ (95\%-os CI: $0,85-1,03 ; \mathrm{p}=0,16)$.
2. táblázat Az eseménymentes túlélés többfaktoros elemzése (a gyógyszeradherencia nem került értékelésre)

\begin{tabular}{llcc}
\hline & Hazárdhányados & $95 \%-$ os CI & $\mathrm{p}$ \\
\hline Életkor* & 2,13 & $1,84-2,46$ & $<0,001$ \\
Nem & 1 & $0,93-1,08$ & 0,9488 \\
PCI & 0,61 & $0,56-0,65$ & $<0,001$ \\
Diabetes mellitus & 1,38 & $1,28-1,49$ & $<0,001$ \\
Hypertonia & 0,98 & $0,88-1,09$ & 0,689 \\
Perifériás érbetegség & 1,47 & $1,34-1,6$ & $<0,001$ \\
Kórelózményben MI & 1,61 & $1,49-1,74$ & $<0,001$ \\
Kórelózményben stroke & 1,36 & $1,23-1,5$ & $<0,001$ \\
\hline
\end{tabular}

$\mathrm{MI}=$ myocardialis infarctus $; \mathrm{PCI}=$ percutan coronariaintervenció *70 vs. 50 éves életkor (az életkor hatása nem lineáris)

3. táblázat |A kórházi elbocsátáskor alkalmazott gyógyszeres kezelés és az egyéves utánkövetésnél észlelt adherencia

\begin{tabular}{lccccc}
\hline & Sztatin & Klopidogrel & Aszpirin & $\begin{array}{l}\text { Béta- } \\
\text { blokkoló }\end{array}$ & $\begin{array}{l}\text { ACEI- } \\
\text { gátló } \\
\text { ARB }\end{array}$ \\
\hline $\begin{array}{l}\text { Kórházi } \\
\text { elbocsátás }\end{array}$ & 88,00 & 88,00 & 89,00 & 84,00 & 79,2 \\
$\leq 10 \%$ & 12,84 & 15,06 & 32,15 & 31,62 & 9,31 \\
$10-20 \%$ & 4,19 & 2,18 & 4,45 & 4,31 & 2,3 \\
$20-30 \%$ & 3,68 & 1,97 & 4,33 & 3,63 & 2,18 \\
$30-40 \%$ & 3,82 & 2,38 & 4,31 & 4,22 & 3,08 \\
$40-50 \%$ & 5,01 & 2,79 & 5,19 & 5,37 & 4,55 \\
$50-60 \%$ & 4,28 & 2,64 & 5,08 & 5,45 & 5,21 \\
$60-70 \%$ & 5,2 & 3,44 & 6,73 & 4,49 & 4,58 \\
$70-80 \%$ & 6,55 & 4,67 & 6,1 & 4,41 & 4,76 \\
$80-90 \%$ & 8,37 & 7,02 & 6,47 & 4,05 & 4,8 \\
$>90 \%$ & 46,06 & 57,84 & 25,19 & 32,44 & 59,22 \\
\hline
\end{tabular}

\section{Az adherencia}

\section{és az elsödleges végpontok összefüggése}

Minden modell esetében elfogadható volt a linearitás és a hazárd proporcionalitása. Az elsődleges végpontok bekövetkezésének HR-ját a 2-6. ábrákon mutatjuk be. A sztatinadherencia összefüggött az elsődleges végpontok bekövetkezésének gyakoriságával: $25 \%$ pontos adherencianövekedés 10\%-kal kisebb újabb infarktus-, illetve halálbekövetkezési kockázattal járt együtt $(\mathrm{HR}=0,899$ $[0,848-0,953], \mathrm{p}=0,003)$. A modell korrigált AUCértéke 74,1\%. A klopidogrel esetén hasonló eredményt kaptunk $(\mathrm{HR}=0,896[0,846-0,950], \mathrm{p}=0,0002 ;$ AUC = 74,1\%). A végpontok legnagyobb arányú rizikócsökkenését az ACEI/ARB esetén figyeltük meg: 15,8\% ( $\mathrm{HR}=$ $0,842[0,793-0,895], \mathrm{p}=0,0001$; AUC = 74,8\%) szintén 25 százalékpontos adherencianövekedésre vonatkozóan. Nem találtunk összefüggést az aszpirinkezelés ( $\mathrm{p}=$ $0,1774)$, illetve a béta-blokkoló terápia $(\mathrm{p}=0,2536)$ 

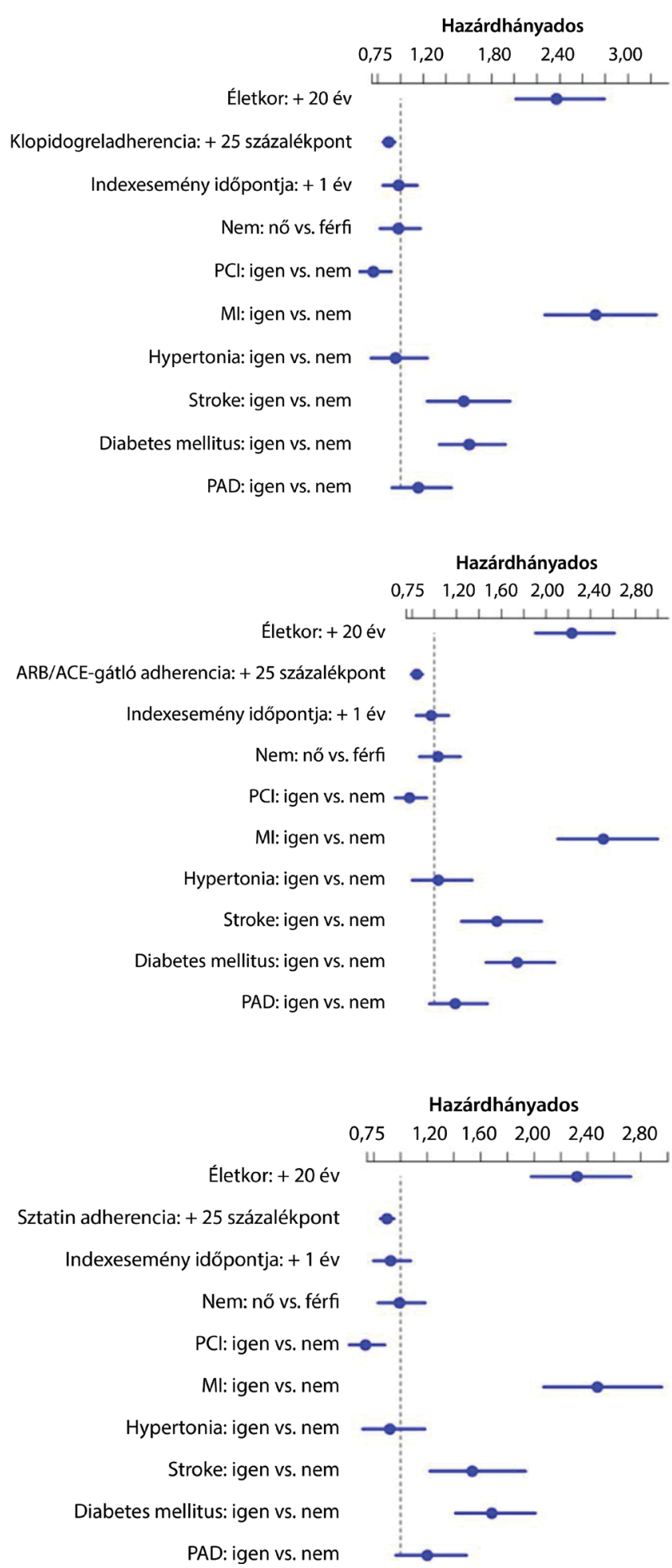

esetén az adherencia és az elsődleges végpontok bekövetkezése között. A modell AUC-értéke 73,8\% és 73,4\% ez esetekben.

\section{Megbeszélés}

Számos vizsgálat igazolta, hogy rendkívül fontos, hogy az infarktust túlélt betegek hosszú távon folytassák a másodlagos prevenció szempontjából igazoltan jelentős
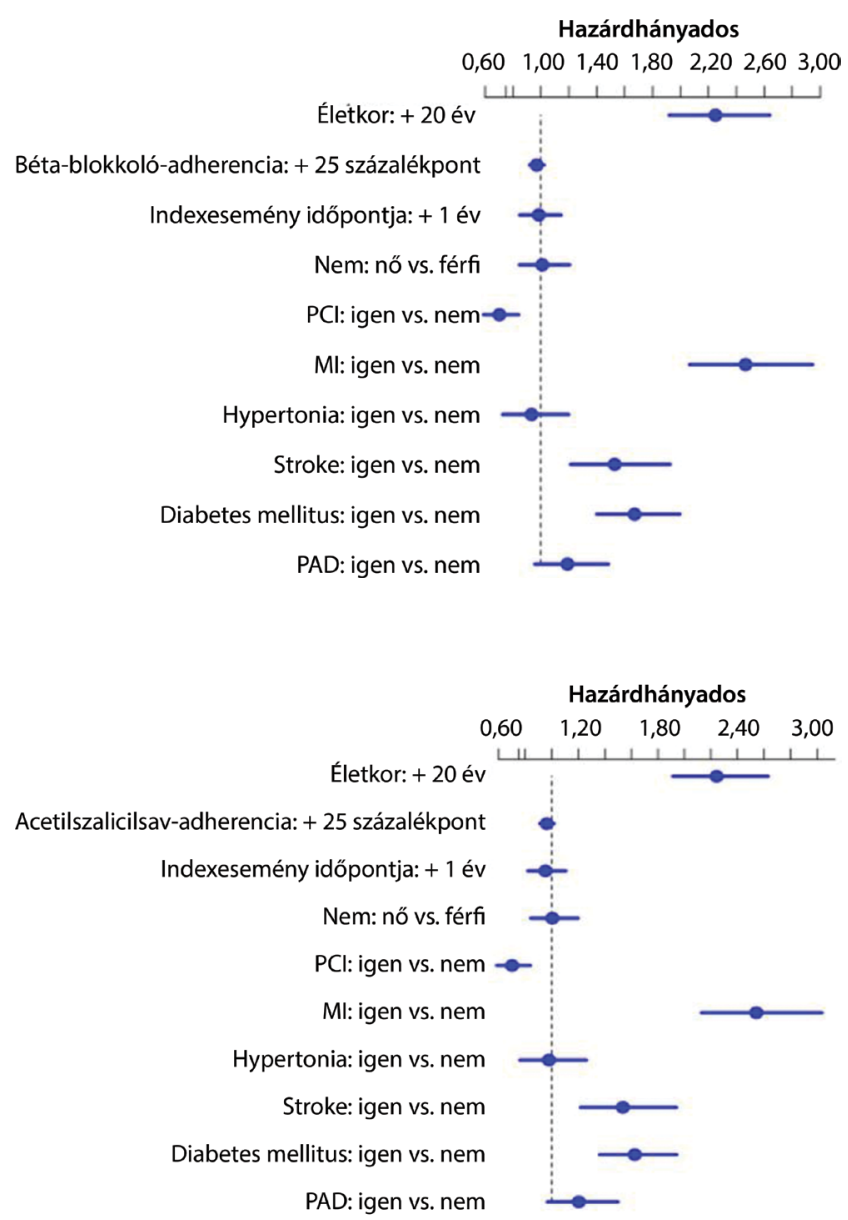

2-6. ábra

Többváltozós túléléselemzés az egyes gyógyszerek adherenciájának figyelembevételével. A pontok a modellben az egyes változókra becsült hazárdhányadosokat mutatják, a vonal az ehhez tartozó 95\%-os konfidenciaintervallum

gyógyszeres kezelést: Chowdhury és mtsai [11] által közölt metaanalízis szerint Európában a cardiovascularis események mintegy 9\%-áért a betegek nem megfelelő adherenciája a felelős. A klinikai vizsgálatokban közölt magas $(\geq 80 \%)$ adherenciaértékeknél a mindennapi gyakorlatban lényegesen alacsonyabb $-30-50 \%$ közötti a betegek terápiahúsége $[12,13]$. A Yusuf [14] által koordinált, több kontinensen végzett PURE vizsgálat megdöbbentố adatokat publikált ebben a kérdésben: igazolta, hogy a szegényebb országokban, illetve a vidéki népesség között különösen alacsony a szekunder prevencióban alkalmazandó gyógyszerek alkalmazása. Vizsgálatunkban a Nemzeti Szívinfarktus Regiszterben retrospektív, obszervációs módszerrel vizsgáltuk az adherenciát és annak hatását az újabb infarktus előfordulására és a halálozásra. A regiszter teljessége (2016-ban a finanszírozott kezelések 84\%-a szerepelt az NSZR adatbázisában) biztosította, hogy a tényleges helyzetet valósan tükröző adatokhoz jussunk. A kórházi elbocsátáskor a betegek több mint $84 \%$-a kapta a másodlagos prevenció szempontjából fontos kezelést. Arnold [15] tanulmá- 
nyában hasonlóan magas volt az elbocsátáskor ezen gyógyszerek aránya. Vizsgálatunkban a megfelelő adherencia $(>80 \%)$ a klopidogrel esetén volt a legmagasabb, ezt követte az ACEI/ARB, sztatin, béta-blokkoló, aszpirin: $64,9 \%, 64 \%, 54,4 \%, 36,5 \%, 31,7 \%$. Az általunk megfigyelt értékek nagyon hasonlóak több korábbi publikációban közölt adatokhoz $[11,16]$. A publikált adherenciaértékek különösen a sztatinok esetén igen hasonlóak és megegyeznek az általunk talált értékkel, annak ellenére, hogy az adherencia definíciója és a vizsgálati módszer számos vizsgálatban különbözött [8, 17-19]. Tomcsányi [6] 6, 12, 24 hónapos sztatinadherenciát vizsgált és megállapította, hogy az „átlagosan elérte a 70\%-ot”. A közleményból azonban nem derül ki egyértelmüen, hogyan változik ez az érték a különböző időpontokban, illetve mit tekintettek megfigyelési végpontnak. A saját vizsgálatunkban az újabb myocardialis infarctus és a halálozás volt a végpont. A két magyarországi vizsgálat közötti különbséget a jelentősen eltérő módszertan magyarázhatja. Vizsgálatunkban igen alacsony aszpirin- $(31,7 \%)$ és alig magasabb $(36,5 \%)$ bétablokkoló-adherenciát találtunk. Úgy gondoljuk, ennek oka, hogy az aszpirin recept nélkül is kapható, valamint az, hogy egyes béta-blokkolók ugyan receptkötelesek, de nem támogatottak. A finanszírozott gyógyszerek OEPnyilvántartása tehát csak megfelelő megszorítással használható az adherencia vizsgálatára. Igazoltuk, hogy a PCI-kezelésben részesülők terápiahüsége magasabb volt, mint az ilyen beavatkozásban nem részesült betegeké. Ez a megfigyelésünk hasonló Kocas [20] közléséhez. Ismeretes, hogy az életkor befolyásolja az adherenciát. Több vizsgálatban az idősebb betegeknél alacsonyabb adherenciát találtak [19, 21-23]. Anyagunkban a legmagasabb terápiahúséget a 60-70 év közötti betegeknél tapasztaltuk, a fiatalabb, illetve a 70 évnél idősebb betegek adherenciája alacsonyabb volt. Megfigyelésünk igen hasonló Tuppin és mtsai [22] közléséhez, akik a 74 év feletti betegek esetén észlelték az adherencia csökkenését. Többváltozós analízis felhasználásával vizsgáltuk az adherencia jelentőségét az újabb infarktus, a halál bekövetkezése szempontjából. Adataink szerint a klopidogrel, a sztatin és az ACEI/ARB esetén a magasabb adherencia szignifikánsan csökkentette a végpontok bekövetkezésének kockázatát. Jernberg [24] a SWEDEHEART regiszterben azt találta, hogy az evidenciákkal alátámasztott gyógyszeres kezelés arányának növekedése javította a betegek prognózisát.

Jelen vizsgálatunk az első hazai tanulmány, amely a szekunder prevencióban jelentőséggel bíró gyógyszerek adherenciáját vizsgálja szívinfarktust túlélt, nagy betegszámú populáció esetén. Vizsgálatunk korlátai közül kiemeljük, hogy a valóságos adherencia nem vizsgálható, mivel olyan módszert nem tudunk igénybe venni, amivel a gyógyszer bevétele egyértelmúen bizonyítható lenne. A recept nélkül kapható, illetve ártámogatásban nem részesülő gyógyszerek tovább nehezítik a valóságos adherencia meghatározását. A vizsgálatunk másik fó limitá- ciója az obszervációs jellege, amely miatt kérdés, hogy valóban az összes fontos confounderre tudtunk-e kontrollálni.

\section{Következtetés}

Az evidenciákkal alátámasztott gyógyszeres kezeléshez való hưséget számtalan tényező befolyásolja, ennek javítása a másodlagos megelőzés fontos része. A gondozó orvos felelőssége a megfelelő életmód és a gyógyszeres kezelés fontosságának hangsúlyozása.

Anyagi támogatás: A közlemény megírása anyagi támogatásban nem részesült.

Szerzôi munkamegosztás: J. A.: Vizsgálati terv elkészítése, a kézirat megírása. O. P.: A kézirat megírásában való részvétel. K. Z.: A nemzetközi irodalom áttekintése. K. L.: Adatgyújtés. K. R. G.: A kéziratban szereplő adatok kritikus értékelése. D. J.: Adatgyújtés, adatok tisztítása. J. Z: A vizsgálati terv elkészítésében való részvétel, adatgyújtés. N. G.: Adatgyújtés, adatok tisztítása. V. G.: A kézirat végleges formájának kialakítása. F. T.: A statisztikai elemzés elkészítése. A cikk végleges változatát valamennyi szerző elolvasta és jóváhagyta.

Érdekeltségek: A szerzőknek nincsenek a kutatással kapcsolatos érdekeltségeik.

\section{Köszönetnyilvánítás}

A szerzők köszönetüket fejezik ki Póth Anikó és Zorándi Ágnes kolléganőknek, a Nemzeti Szívinfarktus Regiszter munkatársainak a kézirat elkészítéséhez nyújtott segítségükért. A szerzők nagyra értékelik azoknak a kollégáknak a tevékenységét, akik folyamatosan, anyagi ellenszolgáltatás nélkül támogatják ennek a fontos szakmai programnak a megvalósítását.

\section{Irodalom}

[1] Sabate E. Adherence to long-term therapies:evidence for action. World Health Organization, Geneva, 2003.

[2] Task Force Members, Montalescot G, Sechtem U, Achenbach S, et al. 2013 ESC guidelines on the management of stable coronary artery disease: The Task Force on the management of stable coronary artery disease of the European Society of Cardiology. Eur Heart J. 2013; 34: 2949-3003.

[3] Nielsen SF, Nordestgaard BG. Negative statin-related news stories decrease statin persistence and increase myocardial infarction and cardiovascular mortality: a nationwide prospective cohort study. Eur Heart J. 2016; 37: 908-916.

[4] Rasmussen JN, Chong A, Alter DA. Relationship between adherence to evidence-based pharmacotherapy and long-term mortality after acute myocardial infarction. JAMA 2007; 297: 177-186

[5] Ho PM, Bryson CL, Rumsfeld JS. Medication adherence: its importance in cardiovascular outcomes. Circulation 2009; 119: 3028-3035.

[6] Tomcsányi J. Adherence to statins in patients with myocardial infarction in Hungary. [Statin gyógyszerszedési gyakorlat myo- 
cardialis infarctus után Magyarországon.] Orv Hetil. 2017; 158: $443-446$.

[7] Szummer K, Lundman P, Jacobson SH, et al. Association between statin treatment and outcome in relation to renal function in survivors of myocardial infarction. Kidney Int. 2011; 79: 9971004.

[8] Kuepper-Nybelen J, Hellmich M, Abbas S, et al. Association of long-term adherence to evidence-based combination drug therapy after acute myocardial infarction with all-cause mortality. A prospective cohort study based on claims data. Eur J Clin Pharmacol. 2012; 68: 1451-1460.

[9] Jánosi A, Ofner P, Merkely B, et al. Short and long term prognosis of patients with myocardial infarction. Hungarian Myocardial Infarction Registry. [Szívinfarktus miatt kezelt betegek korai és késői prognózisa. Magyar Infarctus Regiszter Vizsgálat]. Orv Hetil. 2013; 154: 1297-1302.

[10] Grambsch P, Therneau, TM. Proportional hazards tests and diagnoctics based on weighted residuals. Biometrika 1994; 81 : 515-526.

[11] Chowdhury R, Khan H, Heydon E, et al. Adherence to cardiovascular therapy: a meta-analysis of prevalence and clinical consequences. Eur Heart J. 2013; 34: 2940-2948.

[12] Sackett DL, Haynes RB, Gibson ES, et al. Randomised clinical trial of strategies for improving medication compliance in primary hypertension. Lancet 1975; 1: 1205-1207.

[13] Morris LS, Schulz RM. Patient compliance - an overview. J Clin Pharm Ther. 1992; 17: 283-295.

[14] Yusuf S, Islam S, Chow CK, et al. Use of secondary prevention drugs for cardiovascular disease in the community in high-income, middle-income, and low-income countries (the PURE Study): a prospective epidemiological survey. Lancet $2011 ; 378$ : 1231-1243.

[15] Arnold SV, Spertus JA, Masoudi FA, et al. Beyond medication prescription as performance measures: optimal secondary prevention medication dosing after acute myocardial infarction. J Am Coll Cardiol. 2013; 62: 1791-1801.
[16] Halvorsen S, Jortveit J, Hasvold P, et al. Initiation of and long term adherence to secondary preventive drugs after acute myocardial infarction. BMC Cardiovasc Disord. 2016; 16: 115.

[17] Bansilal S, Castellano JM, Garrido E, et al. Assessing the impact of medication adherence on long-term cardiovascular outcomes. J Am Coll Cardiol. 2016; 68: 789-801.

[18] Newby LK, LaPointe NM, Chen AY, et al. Long-term adherence to evidence-based secondary prevention therapies in coronary artery disease. Circulation 2006; 113: 203-212.

[19] Jackevicius CA, Mamdani M, Tu JV. Adherence with statin therapy in elderly patients with and without acute coronary syndromes. JAMA 2002; 288: 462-467.

[20] Kocas C, Abaci O, Oktay V, et al. Percutaneous coronary intervention vs. optimal medical therapy - the other side of the coin: medication adherence. J Clin Pharm Ther. 2013; 38: 476-479.

[21] Boggon R, van Staa TP, Timmis A, et al. Clopidogrel discontinuation after acute coronary syndromes: frequency, predictors and associations with death and myocardial infarction - a hospital registry-primary care linked cohort (MINAP-GPRD). Eur Heart J. 2011; 32: 2376-2386.

[22] Tuppin P, Neumann A, Danchin N, et al. Evidence-based pharmacotherapy after myocardial infarction in France: adherenceassociated factors and relationship with 30-month mortality and rehospitalization. Arch Cardiovasc Dis. 2010; 103: 363-375.

[23] Al-Khadra S, Meisinger C, Amann U, et al. Secondary prevention medication after myocardial infarction: persistence in elderly people over the course of 1 year. Drugs Aging 2014; 31: 513525.

[24] Jernberg T, Johanson P, Held C, et al. Association between adoption of evidence-based treatment and survival for patients with ST-elevation myocardial infarction. JAMA 2011; 305: $1677-1684$.

(Jánosi András dr., Budapest, Haller utca 29., 1096 e-mail: janosi.andras@kardio.hu)

"Vitam regit fortuna, non sapientia." (Cicero) (A véletlen kormányozza az életet, nem a bölcsesség.) 